\title{
Uncovering the Value of ICT in Time Management for Implementation of OBE Courses
}

\section{Jasma Balasangameshwara}

Associate Professor, Dept. of Computer Science \& Engineering, Atria Institute of Technology - 5600 24, jasma2002@gmail.com

\begin{abstract}
OBE is a reform approach to teaching/learning in which the decisions about the syllabus are determined by the outcomes that the students demonstrate at the end of the course. OBE requires continuous improvement to all phases of training thereby making it a recurring education transformation model. Due to its recurring nature, some of the major drawbacks of institutionalizing OBE are (1) major investment in time for rewriting all learning materials (2) time-consuming to implement OBE assessment methods due to its varied scope and variety of application (3) requires an intensive planning process with taxing activities on the instructors. Use of ICTs play a vital role in efficient time management and bringing about qualitative change in the application of OBE for designing effective courses.
\end{abstract}

This article focuses on representing the potential of existing ICTs to the application of OBE in the design of a post-graduate course prescribed by VTU, India for CS\&E program. Some of the existing ICTs that can be used for effectively implementing the three key OBE elements i.e. content, assessment/feedback and outcomes' achievement evaluation is presented along with an extensive comparison in terms of time investment when practiced with and without the use of

Jasma Balasangameshwara

Associate Professor, Dept. of Computer Science \& Engineering, Atria Institute of Technology - 5600 24,

jasma2002@gmail.com
ICTs. The conclusion drawn after analysis of the time management using ICTs is that they significantly decrease the time spent for application of OBE in analysis of courses. Hence, it is recommended to use one main ICT that is exclusively designed for effective OBE implementation along with other ICTs to significantly save time for other academic \& research activities.

Keywords : Outcome Based Education (OBE), Engineering Education, Information \& Communication Tools (ICT), Time Management, Integrated Course Design

\section{Introduction}

Outcome based education (OBE) is a method of education that lays emphasis on what students can demonstrate after they are trained. Decisions on lessons are made based on how best to facilitate the desired outcome which in turn leads to a preparation process that is different from the traditional preparation [1]. In this regard, many models have been developed to represent the application of OBE in the design of effective courses [2]. The models identify four main elements when planning a course design i.e. course goals, content, assessment/feedback and evaluation of outcomes [1]. Many Institutions and Universities in India have begun to adopt OBE due to its bright vision for education. Nonetheless, practicing OBE adds layers of complexity to the duties of instructors, especially when the instructors are used to traditional lecture based model [3]. 
This can be addressed by the use of Information \& Communication Tools (ICT) which facilitates and enhances teaching and learning. These tools not only provide anytime, anywhere learning opportunities but also significantly decrease the time spent on the application of OBE in the design of effective courses which otherwise have to be implemented manually. However, many Indian academic institutions are not using ICT to provide support to their courses or expand student learning experiences due to lack of awareness, twenty-first century skills or infrastructure [3].

One of the shifts among the five shifts identified by Froyd et al. [3] is the adoption of ICT for improving engineering education in India through OBE. According to the article entitled "Five major shifts in engineering education", even though the use of technology in the design of the courses has the potential to expand choices about teaching and learning; its use in the context of engineering education in India is still in its inception stages [3].

In order to address this issue, Indo-US Collaboration for Engineering Education (IUCEE) introduced a program called Global Education Network for Teaching \& Learning Engineering (GENTLE). The author had an opportunity to undergo training on OBE under the project GENTLE conducted by IUCEE. Following this training, the author has used Inpods platform for post-graduate course for the year 2015 for Computer Science \& Engineering program of Atria Institute of Technology under Visvesvaraya Technological University (VTU). Keeping in mind regarding the published reports on advantages of ICT for OBE, an attempt was made to compare the advantages of ICT over manual methods, particularly in the area of analysis of the data generated using OBE.

This article has the following components.

(a) Use of the some of the available ICTs for OBE by the instructor who had no previous experience in OBE, with the objectives to;

i. Teach the course to enable students attain the course outcomes

ii. Keep track of students continuous progress easily

iii. Examine the students whether the course outcomes have been attained

iv. Routinely examine the assessment process and correct, as needed

(b) Comparison of time investment when OBE is practiced with and without the use of ICTs.
The above mentioned components have been organized as follows. The overview of state of art ICT for OBE application used in this article is presented in section 2. Section 3 reviews related work in literature. Section 4 presents in detail the methodology adopted for integrating ICT in the application of OBE in designing effective courses. A brief outline of the Research Design is presented in Section 5. Results are detailed in section 6 followed by Discussionsand future work in section 7 . Finally section 8 is dedicated to Conclusion and Recommendationsfollowed by Acknowledgement and References.

\section{Background}

\subsection{OBE}

OBE is a philosophy of education in which a student's performance on a number of criteria is continuously monitored [4]. To ensure continuous improvements, the OBE model relies on regularly measuring the achievement of course outcomes along a comprehensive cycle. The main components of the cycle are illustrated in figure 1 [5]. During each phase of the cycle, relevant assessment data is collected for outcomes through assignments/exercises. The collected data is then analyzed against the intended outcomes. The cycle is closed once remedial actions are implemented to address revealed deficiencies [5].

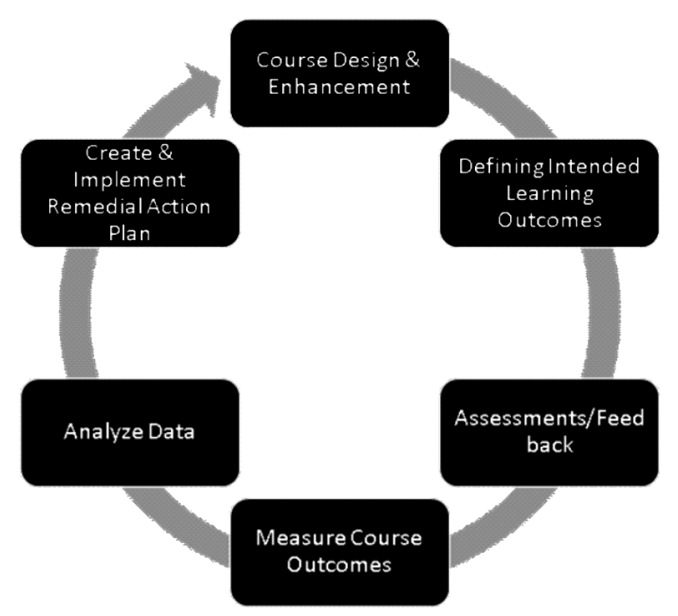

Figure 1. Information Technology Processing Plan [5]

The components highlighted in green in Figure 1 are active learning, assessment/feedback, measuring outcomes and analyzing relevant data, and these are implemented initially by manual analysis and later by using ICT. 


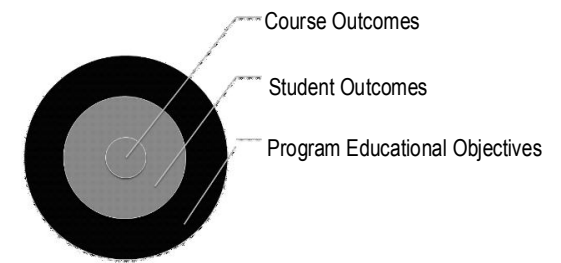

Figure 2. Information Technology Program Assessment Hierarchy [5]

Figure 2 presents the information technology program assessment hierarchy [5]. As indicated in Figure 2, the goal is to analyze student outcomes \& course outcomes and these two are highlighted in green color.

This article has used the designing courses model provided by Fink [7], [8] for designing the postgraduate course titled "Managing Big Data" prescribed by VTU for Computer Science \& Engineering program. The key components of this model that were practiced for the course "Managing Big Data" and time invested were computed (refer results section) with ICT and by manual analysis, and these components are outlined below.

Step 1. Situational factors-They provide the environment against which essential judgements about the course is made. The situational factors that affect the course design are as follows:

A. Context of teaching/learning situation - (i) Number of students in class (ii) Course level (iii) Course time-table (iv) Mode of course delivery (v) Physical learning environment

B. Learning Situation General Context - (i) Course Outcomes

C. Nature of course

D. Characteristics of Learner - (i) Pre-requisites Test (ii) Class goals and expectations identification (iii) Preferred learning styles identification

Step 2. Learning Goals Establishment - From the information developed in situational factors, 'learning goals establishment' identifies the impact of the course on the students after the course is over.

Step 3.Educative Assessment Procedures - These include feedback and assessment procedures designed for making effective courses and enhance the quality of teaching and learning.

i. Forward-Looking Assessment (FLA) - It is created to decide whether students are prepared for some upcoming activity, after the current period of learning is over. FLAs incorporates exercises, questions and/or problems that create a real-life context for a given issue. FLAs are typically open-ended.

ii. Self- Assessment (SA) - It is important for instructors to create opportunities for students to engage in self-assessment of their performance.

iii. Regular Student Feedback Summary (RSFS)

Step 4.Teaching/Learning Activities - (i) Instructor's judgement on active learning activities

Teaching/learning activities reflect the instructor's judgement on how effectively they address the learning goals of the class [7]. Bonwell and Hattie describe active learning as involving students in doing things [8], [9].

Step 5. Integration - This involves the integration of all the previously mentioned steps. (i) Instructor's judgement on in-class and out-of class activities.

\subsection{State of art ICTs for application of OBE}

Some of the existing ICTs used in this article are presented in the subsequent sections.

\subsubsection{Inpods}

Inpods is a cloud-based learning environment with focus on social learning and easy to use analytics to enhance speed and quality of learning. It enables creation of MOOC-like course content, tracking \& analyzing student performance as well as achievement of course outcomes. Inpods can facilitate use of latest approaches to active learning such as flipped learning. It is an application that helps instructors use their time more productively.

Advantages of using Inpods for OBE are

1. It integrates course planning, active learning, assessments evaluation, course outcomes analysis in a systematic way.

2. It maintains assessment and analysis records and does computational formulation of assessment results.

Inpods Platform Features

The question types supported on Inpods are

૫ Automated Evaluation - Fill in the blanks, Match the following and Multiple choice

૫ Manual Evaluation- Correct or incorrect word usage and Discussion Question

( Assessment Types supported on InpodsHomework, Test, Exam, Project and External 
( Reports generated by Inpods

口 Student Outcomes - Percentage Performance per Concept

u Lesson Concept Coverage

\ Concepts \& Questions per Concept

口 Bloom's Category Question Report

૫ Section's Report - Student Effort \& Percentage Performance

\subsubsection{Google Forms \& MS Excel 2013}

Student feedback and ratings on course are one of the most powerful influences on learning and achievement [9]. They are one among the key components of OBE for continuous improvement and reflect that the OBE model helps foster an atmosphere for learning. However manually conducting and analyzing student feedback is not only labor intensive but also time consuming. One of the ICT that can ease the feedback management is Google Forms. Google Forms is a free tool that provides quick ways to create online surveys with responses collected on online spreadsheets for analysis after importing to MS Excel 2013.

\subsubsection{Microsoft Office Mix for PowerPoint}

As shown in figure 1, active teaching/learning forms the heart of OBE model for continuous improvement. This can be achieved by using the Microsoft Office Mix for PowerPoint. It is a free addin for PowerPoint for creating and sharing interactive lessons online. This add-in is built for instructors. Microsoft Office Mix also tracks usage of the presentation by students, giving instructor analytics on data; like which students accessed the mix, how many answers they got right and how much time they spent on each slide. Microsoft Office Mix for PowerPoint was used for aiding students in selfassessment.

Analytics provided by Microsoft Office Mix

૫ PowerPoint Slide Summary- Number of visitors, number of views, average time spent per slide, percentage correct answers per slide (applicable if the slide has quiz), number of attempts to solve the quiz

( Quiz - Number of views, time taken to complete the quiz, percentage correct, number of attempts
口 Viewer Statistics - Slide progress percentage, number of quizzes and polls taken, percentage correct, overall time spent

\subsubsection{Microsoft Office Online}

Microsoft Office Online is a free service offered by Microsoft. The service provides online access to Microsoft Office tools like MS Word, MS Excel to name a few. These tools can be used for sharing documents and working together at the same time on the same document. This ICT is a great tool for realtime online collaboration and assists active learning and collaborative learning among students. Microsoft Office Online can be accessed through Microsoft Hotmail or Outlook accounts.

\section{Literature Review}

Assessment/feedback analysis and evaluation of outcomes are essential elements of OBE. However, the collection, aggregation and analysis of these two elements is a complex, time-consuming and laborintensive process which is mostly paper-based [5]. For example, the University of Alberta, Edmonton, Canada estimated an overall analysis time of 16,000 $\mathrm{man} /$ hours for nine of their engineering programs [10].

According to Bill L.P. Lee and Stephen Mak [11], there has been limited study on use of ICT for supporting OBE. Many Indian academic institutions are not using ICT to support their courses or expand student learning experiences due to lack of awareness, twenty-first century skills or infrastructure [5]. Hence, there is a need for integrating use of electronic processes and ICTs into the application of OBE. Walid Ibrahim et al. [5] in their article entitled "A WebBased Course Assessment Tool with Direct Mapping to Student Outcomes" published in the year 2015 reported that there are only few developments on ICTs for effective implementation of OBE [10], [11], [12], [13].Lee et al [9] have presented a web-based academic records tracking system for OBE. The key features of the work includes teaching/learning activity management, assessment \& reporting. However, most of these systems are not available for public use or have been designed in an ad-hoc way fulfilling the needs of a specific institution. Thus, there is currently a clear need of making use of available ICTs for automating the application of OBE in the design of effective courses. 
Hence, this article focuses on signifying the value of existing ICTs to the application of OBE in time management of the design \& analysis of a postgraduate course titled "Managing Big Data" prescribed by VTU, India for Computer Science \& Engineering program. Some of available ICTs that can be used for effectively implementing the three key OBE elements i.e. content, assessment/feedback and course outcomes' achievement evaluation is presented along with an extensive judgement in terms of time investment when accomplished with and without the use of ICTs.

\section{Methods \& Materials}

4.1 Integrating existing ICTs for implementation of OBE-BriefOverview

The existing OBE software tools that are used in this article are (I) Inpods, (2) Google Forms, (3) MS Excel 2013 (4) Microsoft Office Mix for PowerPoint $\&$ (5) Microsoft Office Online. These were used to serve a variety of roles, ranging from course content delivery, e-learning, course outcomes assessments, outcomes data management and learning outcomes analytics (refer Table 1).

\subsection{Methodology}

The methodology adopted in implementation of OBE for the design of the course is based on model provided by Fink [6], [7] and is detailed in Table 1 as given below.

Table 1

Details of Steps in OBE Implementation and the Methods used for each of them

\begin{tabular}{|c|c|c|c|}
\hline \multirow{2}{*}{$\begin{array}{c}\text { Step } \\
\text { ID }\end{array}$} & \multirow{2}{*}{ Step } & \multicolumn{2}{|c|}{ Methodology } \\
\hline & & Manual & \begin{tabular}{|r|} 
ICT \\
\end{tabular} \\
\hline $\begin{array}{l}\text { Bi- } \\
\text { COs }\end{array}$ & $\begin{array}{l}\text { Situational factors - } \\
\text { Learning Situation } \\
\text { General Context - } \\
\text { Course Outcomes } \\
\text { (COs) } \\
\text { Situational factors - } \\
\text { Characteristics of } \\
\text { Learner - Pre- } \\
\text { requisites Test } \\
\text { (PRTest) }\end{array}$ & $\begin{array}{l}\text { Identification of } \\
\text { COs, Mapping of } \\
\text { chapters/lessons to } \\
\text { COs, identification } \\
\text { of learning outcomes } \\
\text { (LOs), mapping of } \\
\text { LOs-COs using MS } \\
\text { Excel 2013. }\end{array}$ & $\begin{array}{l}\text { COs fed to Inpods, } \\
\text { Inpods provides } \\
\text { user-interface for } \\
\text { mapping of } \\
\text { chapters/lessons to } \\
\text { COs. LOs are } \\
\text { specified for the } \\
\text { lesson during its } \\
\text { design and upload to } \\
\text { Inpods. }\end{array}$ \\
\hline $\begin{array}{l}\text { 1Di- } \\
\text { PR } \\
\text { Test }\end{array}$ & $\begin{array}{l}\text { Situational factors } \\
\text { - Characteristics of } \\
\text { Learner - Pre- } \\
\text { requisites Test } \\
\text { (PRTest }\end{array}$ & $\begin{array}{l}\text { Pre-requisites quiz } \\
\text { was designed using } \\
\text { MS Word } 2013 \text { and } \\
\text { projected in class. } \\
\text { Students answer the } \\
\text { test in their } \\
\text { assignment book and } \\
\text { submit to instructor } \\
\text { with in the class } \\
\text { hour. Instructor } \\
\text { evaluates manually } \\
\text { and summaries the } \\
\text { results using MS } \\
\text { Excel } 2013 \text {. }\end{array}$ & $\begin{array}{l}\text { Pre-requisites quiz } \\
\text { online links } \\
\text { uploaded on } \\
\text { Inpods. The online } \\
\text { quiz system } \\
\text { automatically } \\
\text { evaluates the quiz } \\
\text { and scores } \\
\text { immediately. } \\
\text { Students take the } \\
\text { quiz and announce } \\
\text { the score to } \\
\text { instructor, which is } \\
\text { entered in MS } \\
\text { Excel } 2013\end{array}$ \\
\hline
\end{tabular}

\begin{tabular}{|c|c|c|c|}
\hline \multirow{2}{*}{$\begin{array}{c}\text { Step } \\
\text { ID }\end{array}$} & \multirow{2}{*}{ Step } & \multicolumn{2}{|c|}{ Methodology } \\
\hline & & Manual & ICT \\
\hline $\begin{array}{c}3 \mathrm{i}- \\
\text { FLAE }\end{array}$ & $\begin{array}{l}\text { Educative } \\
\text { Assessment } \\
\text { Procedures - } \\
\text { Forward Looking } \\
\text { Assessment } \\
\text { Evaluation } \\
\text { (FLAE) }\end{array}$ & $\begin{array}{l}\text { An open-ended } \\
\text { problem was designee } \\
\text { using MS Word } 2013 \\
\text { and projected in class } \\
\text { Students solve in thei } \\
\text { assignment book and } \\
\text { submit to instructor. } \\
\text { Instructor evaluates } \\
\text { manually and } \\
\text { summaries the results } \\
\text { using MS Excel } 2013\end{array}$ & $\begin{array}{l}\text { An open-ended } \\
\text { question is } \\
\text { uploaded on } \\
\text { Inpods with } \\
\text { assessment type } \\
\text { as group activity. } \\
\text { Students solve } \\
\text { using Microsoft } \\
\text { Office Online and } \\
\text { submit solution } \\
\text { on Inpods. } \\
\text { Instructor checks } \\
\text { the solution and } \\
\text { assigns grade on } \\
\text { Inpods. Inpods } \\
\text { automatically } \\
\text { summaries the } \\
\text { assessment } \\
\text { results. }\end{array}$ \\
\hline $\begin{array}{c}3 \mathrm{ii}- \\
\text { SAD }\end{array}$ & $\begin{array}{l}\text { Educative } \\
\text { Assessment } \\
\text { Procedures - Self- } \\
\text { Assessment } \\
\text { Delivery (SAD }\end{array}$ & $\begin{array}{l}\text { Self - assessment } \\
\text { quiz was designed } \\
\text { using MS Word } 2013 \\
\text { and projected in } \\
\text { class. Students } \\
\text { answer the test in } \\
\text { their assignment } \\
\text { book and peer- } \\
\text { evaluate. Instructor } \\
\text { announces the } \\
\text { correct answer and } \\
\text { students self- } \\
\text { evaluate.Instructor } \\
\text { verifies manually } \\
\text { and summaries the } \\
\text { results using MS } \\
\text { Excel } 2013 \text {. }\end{array}$ & $\begin{array}{l}\text { Self - assessment } \\
\text { quiz is designed and } \\
\text { uploaded on Inpods } \\
\text { or through } \\
\text { Microsoft Office } \\
\text { Mix. The online } \\
\text { quiz system } \\
\text { automatically } \\
\text { evaluates the quiz } \\
\text { and scores } \\
\text { immediately. } \\
\text { Students take the } \\
\text { quiz and know their } \\
\text { score instantly. } \\
\text { Inpods or Microsoft } \\
\text { Office Mix } \\
\text { automatically } \\
\text { summaries student } \\
\text { performance. }\end{array}$ \\
\hline $\begin{array}{c}3 \text { iii- } \\
\text { RSFS }\end{array}$ & $\begin{array}{l}\text { Educative } \\
\text { Assessment } \\
\text { Procedures - Self- } \\
\text { Assessment } \\
\text { Delivery (SAD) }\end{array}$ & $\begin{array}{l}\text { Self - assessment } \\
\text { quiz was designed } \\
\text { using MS Word } 2013 \\
\text { and projected in } \\
\text { class. Students } \\
\text { answer the test in } \\
\text { their assignment } \\
\text { book and peer- } \\
\text { evaluate. Instructor } \\
\text { announces the } \\
\text { correct answer and } \\
\text { students self- } \\
\text { evaluate.Instructor } \\
\text { verifies manually and } \\
\text { summaries the results } \\
\text { using MS Excel } \\
2013 \text {. }\end{array}$ & $\begin{array}{l}\text { Self - assessment } \\
\text { quiz is designed and } \\
\text { uploaded on Inpods } \\
\text { or through } \\
\text { Microsoft Office } \\
\text { Mix. The online } \\
\text { quiz system } \\
\text { automatically } \\
\text { evaluates the quiz } \\
\text { and scores } \\
\text { immediately. } \\
\text { Students take the } \\
\text { quiz and know their } \\
\text { score instantly. } \\
\text { Inpods or Microsoft } \\
\text { Office Mix } \\
\text { automatically } \\
\text { summaries student } \\
\text { performance. }\end{array}$ \\
\hline $\begin{array}{c}\text { 3iii- } \\
\text { RSFS }\end{array}$ & $\begin{array}{l}\text { Educative } \\
\text { Assessment } \\
\text { Procedures - } \\
\text { Regular Student } \\
\text { feedback } \\
\text { Summary }\end{array}$ & $\begin{array}{l}\text { Feedback questions } \\
\text { are dictated in } \\
\text { class, students } \\
\text { provide their } \\
\text { feedback on sheets. } \\
\text { Instructor collects } \\
\text { the sheets, enters } \\
\text { and summaries the } \\
\text { results using MS } \\
\text { Excel 2013. }\end{array}$ & $\begin{array}{l}\text { Instructor provides } \\
\text { web link to } \\
\text { feedback form } \\
\text { developed using } \\
\text { Google forms. } \\
\text { Students provide } \\
\text { their feedback } \\
\text { which is stored on } \\
\text { Google Sheets. } \\
\text { Instructor } \\
\text { summaries the } \\
\text { results on Google } \\
\text { Sheets }\end{array}$ \\
\hline
\end{tabular}




\begin{tabular}{|c|c|c|c|}
\hline \multirow{2}{*}{$\begin{array}{c}\text { Step } \\
\text { ID }\end{array}$} & \multirow{2}{*}{ Step } & \multicolumn{2}{|c|}{ Methodology } \\
\hline & & Manual & ICT \\
\hline $\begin{array}{c}4 \mathrm{i}- \\
\text { ALA }\end{array}$ & $\begin{array}{l}\text { Teaching/Learning } \\
\text { Activities - } \\
\text { Instructor's } \\
\text { judgement on } \\
\text { Active Learning } \\
\text { Activities (ALA }\end{array}$ & $\begin{array}{l}\text { Students perform the } \\
\text { activity on their } \\
\text { notebooks. Instructor } \\
\text { evaluates manually } \\
\text { and summaries the } \\
\text { activity performance } \\
\text { using MS Excel } 2013 \text {. }\end{array}$ & $\begin{array}{l}\text { An active learning } \\
\text { activity is uploaded } \\
\text { on Inpods with } \\
\text { assessment type as } \\
\text { group activity. } \\
\text { Students solve } \\
\text { using Microsoft } \\
\text { Office Online and } \\
\text { submit solution on } \\
\text { Inpods. Instructor } \\
\text { checks the solution } \\
\text { and assigns grade } \\
\text { on Inpods. Inpods } \\
\text { automatically } \\
\text { summaries the } \\
\text { assessment results. }\end{array}$ \\
\hline $\begin{array}{l}5 \mathrm{i}^{-} \\
\mathrm{OA}\end{array}$ & $\begin{array}{l}\text { Integration - Out- } \\
\text { of class Activities } \\
\text { (OAs) }\end{array}$ & $\begin{array}{l}\text { Instructor dictates } \\
\text { homework questions. } \\
\text { Students provide } \\
\text { solution in their } \\
\text { assignment book and } \\
\text { submit to instructor. } \\
\text { Instructor evaluates } \\
\text { manually and } \\
\text { summaries the } \\
\text { activity performance } \\
\text { using MS Excel } 2013 \text {. }\end{array}$ & $\begin{array}{l}\text { An out-of class } \\
\text { activity is uploaded } \\
\text { on Inpods with } \\
\text { assessment type as } \\
\text { group activity. } \\
\text { Students } \\
\text { collaborate in real- } \\
\text { time outside the } \\
\text { class and solve } \\
\text { using Microsoft } \\
\text { Office Online and } \\
\text { submit solution on } \\
\text { Inpods. Instructor } \\
\text { checks the solution } \\
\text { and assigns grade } \\
\text { on Inpods. Inpods } \\
\text { automatically } \\
\text { summaries the } \\
\text { assessment results. }\end{array}$ \\
\hline $\begin{array}{l}1 \mathrm{Ai}- \\
\mathrm{Att}\end{array}$ & $\begin{array}{l}\text { Situational } \\
\text { factors-Context } \\
\text { of teaching } \\
\text { learning situation } \\
\text { - Number of } \\
\text { students in class }\end{array}$ & $\begin{array}{l}\text { Students' } \\
\text { university ID and } \\
\text { names were } \\
\text { entered to } \\
\text { attendance register. } \\
\text { Daily attendance \& } \\
\text { student } \\
\text { performance was } \\
\text { monitored through } \\
\text { attendance register. }\end{array}$ & $\begin{array}{l}\text { Student names } \\
\text { and email ID's } \\
\text { were fed to } \\
\text { Inpods, Students' } \\
\text { university ID and } \\
\text { names were } \\
\text { entered on MS } \\
\text { Excel 2013. Daily } \\
\text { attendance \& } \\
\text { student } \\
\text { performance was } \\
\text { monitored using } \\
\text { MS Excel 2013. }\end{array}$ \\
\hline
\end{tabular}

4.3 Manual Analysis

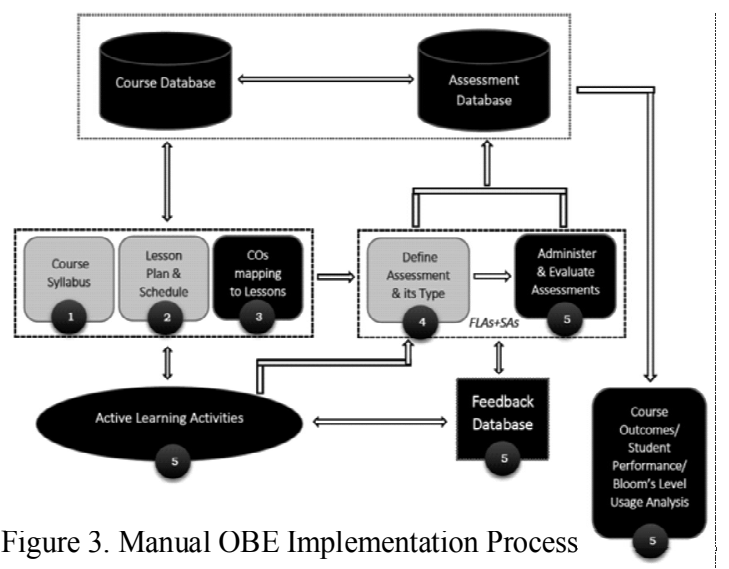

Figure 3 highlights manual OBE implementation processes. The five implementation steps depicted in figure 3 numbered 1 to 5 are the components, of which 'course syllabus', 'lesson plan and schedule' and 'define assessment and its type' are developed by manual process only. The others including components numbered 3 and 5 and databases 'COs mapping to lessons', 'administer and evaluate assessments' , 'course \& student outcomes', 'feedback' and 'active learning activities' and 'course database' and 'assessment database' respectively can be analyzed by either manual methods or using ICTs as done in this study.

Figure 4 represents the tasks that any instructor has to undertake for practicing OBE. Use of ICT for efficient time management is at the heart of all activities such as Evaluation \& Reflection, Outcome Assessment, Course Design, Academic Reporting, Follow-up \& Monitoring, Personalized Learning Environment and Collective Collaboration.

\subsection{Using ICTs}

As shown in table 2, Inpods is the ICT that automates the implementation of most of the OBE elements and evaluates the overall quality of OBE course. However, the other ICTs listed below aid the instructor in effective delivery of the course and analysis of relevant data. These ICTs (MS Word, MS Excel and MS PowerPoint) are routinely used thereby reducing the time that the instructor needs to invest on learning \& gaining expertise on new tools.

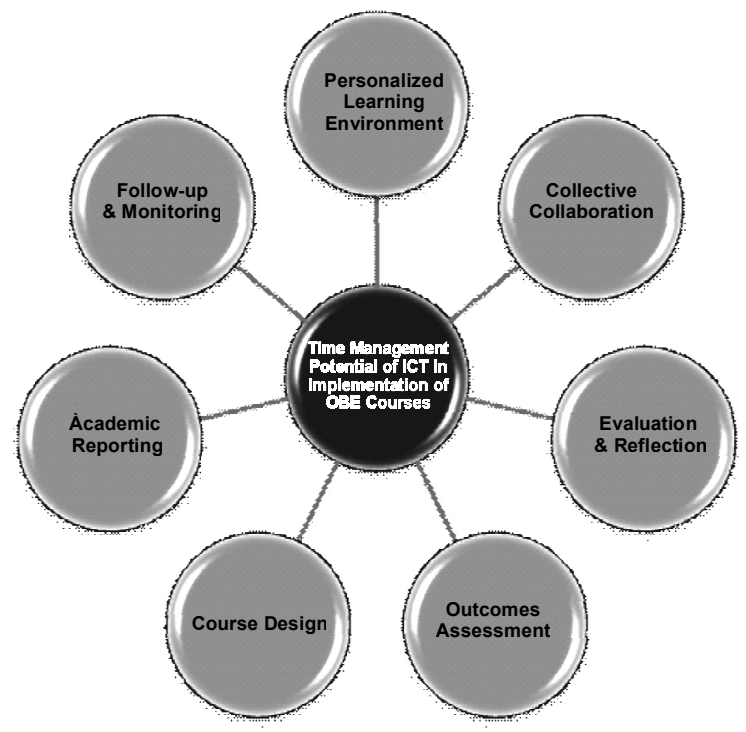

Figure 4. Time management Potential of ICT in the Implementation of OBE Courses 
Table 2.

OBE Components-ICT Usage

\begin{tabular}{|r|l|l|}
$\begin{array}{r}\text { Sl. } \\
\text { No. }\end{array}$ & \multicolumn{1}{|c|}{ ICT Name } & \multicolumn{1}{|c|}{ Usage in OBE } \\
\hline 1. & Inpods & $\begin{array}{l}\text { Course \& Assessment Database, COs } \\
\text { Mapping to Lessons, Assessment } \\
\text { Mapping to Bloom's Level, } \\
\text { Administer \& Evaluation of } \\
\text { Assessments, Administer \& } \\
\text { Conduction of Active Learning } \\
\text { Activities, Course Outcomes/Student } \\
\text { Outcomes/Bloom's Level Usage } \\
\text { Analysis }\end{array}$ \\
\hline 2. & Microsoft Office Mix & $\begin{array}{l}\text { Design \& Conduction of Active } \\
\text { Learning Activities, Lesson wise } \\
\text { Analytics on Student Performance }\end{array}$ \\
\hline 3. & $\begin{array}{l}\text { Google Forms \& MS } \\
\text { Excel 2013 }\end{array}$ & $\begin{array}{l}\text { Feedback Database, Administering, } \\
\text { Evaluation \& Analysis of feedback } \\
\text { data }\end{array}$ \\
\hline 4. & Microsoft Office Online & $\begin{array}{l}\text { Conduction of Active Learning } \\
\text { Activities through Real-Time } \\
\text { Collaboration }\end{array}$ \\
\hline
\end{tabular}

Figure 5 is a replication of figure 3 and depicts the activities \& ICTs used to analyze them.

In the implementation of OBE for the design of effective courses, Inpods platform provided an automation for the mapping of outcomes to course content, administering \& delivery of active learning activities, administering, delivery \& evaluation of forward-looking assessments (FLAs) \& selfassessments (SAs) and analysis of course outcomes, student performance and Bloom's level usage in the course. For successful practicing of OBE, Microsoft Office Mix for PowerPoint assisted in creation of interactive PowerPoint presentations with quizzes

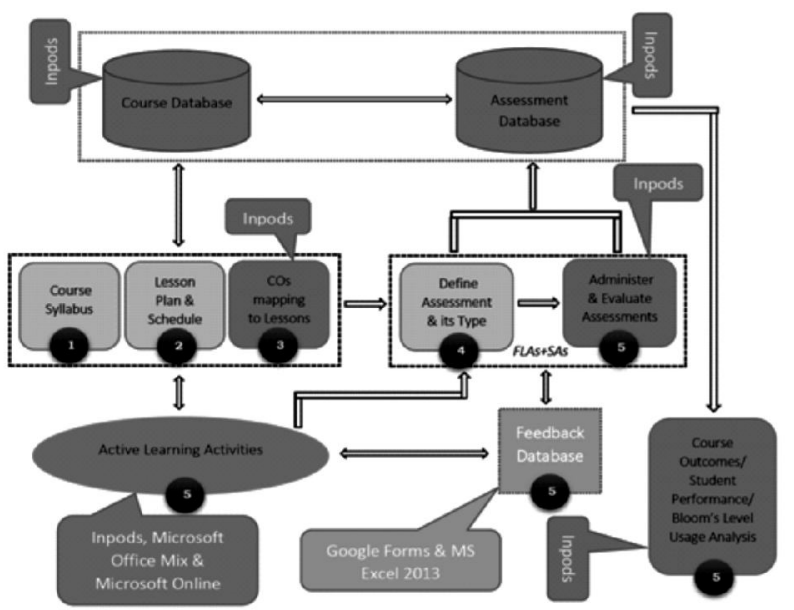

Figure 5. OBE Implementation Processes using ICTs and polls for empowering students to self-assess themselves and aid the instructor in administering active learning activities and monitoring students' progress and effort on self-assessment. Microsoft Office Online aided in real-time collaboration, Google Forms \& MS Excel 2013 for analytics on course feedback data.

\section{Research Design}

Keeping in mind the objective of assessing the value of existing ICTs to OBE in time management of the design \& analysis of a post-graduate course prescribed by VTU for CSE program, the following design was developed; (a) Selection of procedures for Manual Analyses as controls for ICT (see Figure 3 for processes), (b) allotment of maximum time for one sessionof each step (refer Table 1) based on existing institutional norms for manual analysis, followed by timing of one session for all ten identified Steps both by Manual Analysis and by ICTs. This is followed by testing the results for statistical significance, calculation of the Standard Deviation and 95\% confidence limit for total time required for Manual Analysis and ICT of one session of all steps, (c) estimation and analysis of the total time required for all sessions conducted for all steps by Manual Analysis and ICT, followed by calculation of the Standard Deviation and $95 \%$ confidence limit for total time required for Manual Analysis and ICT of all sessions of all steps and their comparative analysis in relation to time allotted for each session and time saved, if any, by ICT compared to Manual Analysis and (d) analysis of Percent of Total Estimated time Saved by Instructor by using ICT Compared to Manual Analysis for all sessions by Steps and by individual ICTs.

\section{Results}

6.1 Time Allotted and Utilized for One Session of each Step by Manual Analysis and using ICT (Table 3 \& Figure 6)

Table 3 provides information regarding the time taken to analyze ten below mentioned steps by manual methods and by ICT. The maximum time allotted for each session of each step as per the time schedule of the instructor is provided, which were pre-defined for manual analysis. The manual methods were used for one session followed by ICTs for all sessions. The time was recorded in Hours.Minutes. Seconds format 
for all. The analysis below is for one session of each step. The table however has time shown in seconds as one of the steps for which ICT was used was completed in less than a minute and hence for uniformity all results in the table were computed in seconds. It can be seen that the time invested by the instructor ranged from $13 \%$ to $100 \%$ for manual analysis and $5 \%$ to $22 \%$ for ICT in comparison with the maximum time allotted.

Table 3.

Details of Time Allotment, Utilization in Seconds* and Percent Utilization for One Session of Steps by Manual Analysis and ICT

\begin{tabular}{|c|c|c|c|c|c|}
\hline $\begin{array}{c}\text { Step } \\
\text { ID }\end{array}$ & \begin{tabular}{|c|} 
Step \\
Freque \\
ncy
\end{tabular} & $\begin{array}{l}\text { Implementation } \\
\text { Details for } \\
\text { each session } \\
\text { Attendance }\end{array}$ & $\begin{array}{l}\text { Time } \\
\text { allotted } \\
\text { in } \\
\text { seconds } \\
\text { per } \\
\text { session }\end{array}$ & \begin{tabular}{|c|} 
Time Invested by \\
Instructor in \\
seconds for Manual \\
analysis for \\
one session \\
(Percent of \\
total allotted \\
time for \\
the session)
\end{tabular} & $\begin{array}{l}\text { Time Invested } \\
\text { by Instructor } \\
\text { (in seconds) } \\
\text { - using ICT } \\
\text { for one session } \\
\text { (Percent of total } \\
\text { allotted time for the } \\
\text { session) }\end{array}$ \\
\hline $\begin{array}{l}\text { 1Ai- } \\
\text { Att }\end{array}$ & Daily & $\begin{array}{l}\text { Attendance } \\
\text { analysis in } \\
\text { register vs. Excel }\end{array}$ & 300 & $93(31 \%)$ & $23(8 \%)$ \\
\hline $\begin{array}{l}\text { 1Ai- } \\
\text { Att }\end{array}$ & Weekly & $\begin{array}{l}\text { Attendance } \\
\text { analysis in } \\
\text { register vs. Excel }\end{array}$ & 1200 & $900(75 \%)$ & $60(5 \%)$ \\
\hline $\begin{array}{l}1 \mathrm{Bi}- \\
\mathrm{Cos}\end{array}$ & $\begin{array}{l}\text { Per } \\
\mathrm{CO} \\
\end{array}$ & $\begin{array}{l}\text { Mapping of LOs } \\
\text { to CO - Manual } \\
\text { Vs Inpods } \\
\end{array}$ & 3600 & $473(13 \%)$ & $183(5 \%)$ \\
\hline $\begin{array}{l}\text { 1Di- } \\
\text { PR } \\
\text { Test }\end{array}$ & Once & $\begin{array}{l}\text { Evaluation and } \\
\text { analysis of } \\
\text { Pre-Requisite test - } \\
\text { Manual Vs. Inpods }\end{array}$ & 300 & $1801(50 \%)$ & $541(15 \%)$ \\
\hline $\begin{array}{l}3 \mathrm{i}- \\
\text { FLAE }\end{array}$ & $\begin{array}{l}\text { Once } \\
\text { every } \\
\text { week }\end{array}$ & $\begin{array}{l}\text { Analysis of FLAE - } \\
\text { Manual vs. } \\
\text { Microsoft Azure } \\
\text { \& Inpods }\end{array}$ & 7200 & $4200(58 \%)$ & $900(13 \%)$ \\
\hline $\begin{array}{l}3 \mathrm{iii} \\
\text { SAD }\end{array}$ & $\begin{array}{l}\text { Once } \\
\text { every } \\
\text { week }\end{array}$ & $\begin{array}{l}\text { SAD - Manual } \\
\text { vs. Microsoft } \\
\text { Office Mix }\end{array}$ & 3300 & $3300(100 \%)$ & $540(16 \%)$ \\
\hline $\begin{array}{l}3 \mathrm{ii}- \\
\text { SAE }\end{array}$ & $\begin{array}{l}\text { Once } \\
\text { every } \\
\text { week }\end{array}$ & $\begin{array}{l}\text { SAE -Manual } \\
\text { Vs. Microsoft } \\
\text { Office Mix }\end{array}$ & 2700 & $1200(44 \%)$ & $600(22 \%)$ \\
\hline $\begin{array}{l}\text { 3iii- } \\
\mathrm{SAEE}\end{array}$ & \begin{tabular}{|l|} 
Once \\
every \\
Month \\
\end{tabular} & $\begin{array}{l}\text { RSFS- } \\
\text { Summarizing } \\
\text { Manually vs. } \\
\text { Google Forms } \\
\text { \& Sheets }\end{array}$ & 1800 & $1320(73 \%)$ & $300(17 \%)$ \\
\hline $\begin{array}{l}\text { 4i- } \\
\text { ALA }\end{array}$ & $\begin{array}{l}\text { Once } \\
\text { every } \\
\text { week }\end{array}$ & $\begin{array}{l}\text { ALA - } \\
\text { Summarizing } \\
\text { Manual Vs. Inpods }\end{array}$ & 3600 & $2700(75 \%)$ & $122(3 \%)$ \\
\hline $\begin{array}{l}5 \mathrm{i}- \\
\mathrm{OA}\end{array}$ & $\begin{array}{l}\text { Once } \\
\text { every } \\
\text { Month }\end{array}$ & $\begin{array}{l}\text { OA assessment - } \\
\text { Manual Vs. } \\
\text { Microsoft } \\
\text { Online \& Inpods }\end{array}$ & 3600 & $2160(60 \%)$ & $600(17 \%)$ \\
\hline
\end{tabular}

* The time was recorded in Hours:Minutes : Seconds format and converted to seconds as one of the results was less than a minute
The difference in time invested by the instructor for manual analysis and ICT were statistically highly significant $(<0.00001)$ for all steps (not shown in table). StatCalc of EPI INFO 7 version 7.1.4.0 was used to test the levels of significance.

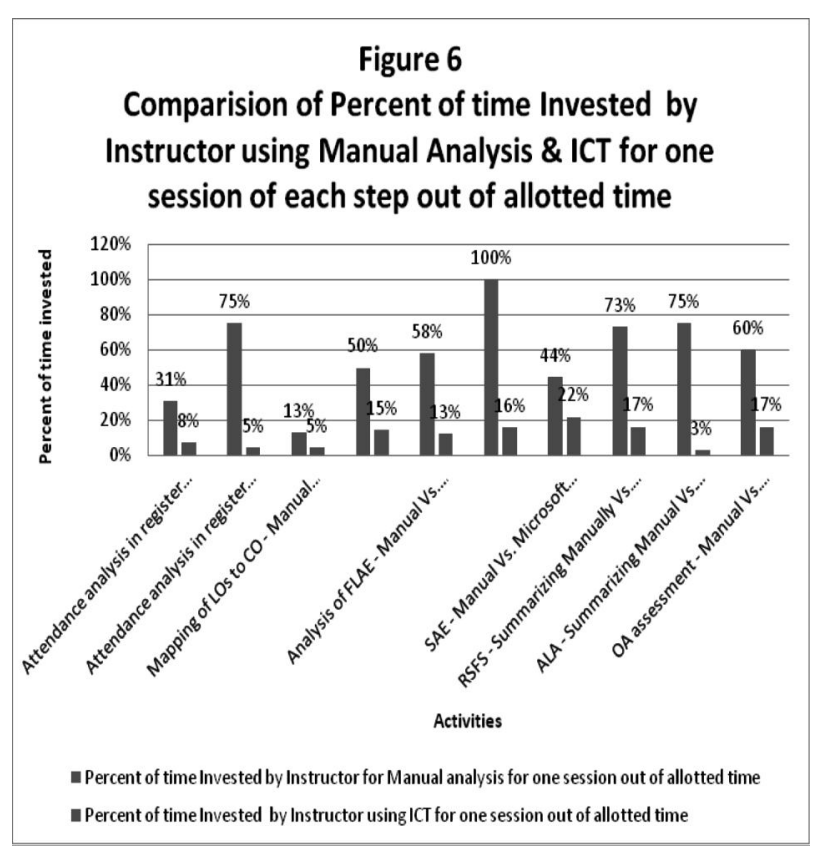

Figure 6 highlights the difference in the proportion of time invested by instructor when the manual and ICT analysis are compared.

\section{StatCalc-EPIINFO 7:https://wwwn.cdc.gov/epiinfo/user- guide/StatCalc/introduction.html3}

\subsection{Total Number of Sessions \& Estimated Time Utilized and Saved in Minutes for All Session of Each Step by Manual Analysis and ICT (Table 4)}

Table 4 provides the estimates of the time in minutes that the instructor should have invested if manual analysis for all sessions of each step as well as estimates of time that the instructor has invested using ICT for all sessions of each step. The computation of time in minutes as several steps had a total of less than one hour.The total estimated time in minutes by manual analysis ranged from 30 to 910 minutes compared to 9 to 195 minutes using ICT. The advantage of ICT lies in that it has saved time ranging from 21 minutes to 715 minutes for all sessions taken together. 
Table 4.

Details of Total Number of Sessions, Estimated Time Utilized and Estimated Time Saved in Minutes* for All Sessions of all Steps by Manual Analysis and ICT zed and Estimated Time Saved in Minutes* for All Sessions of all Steps by Manual Analysis and ICT

\begin{tabular}{|c|c|c|c|c|c|c|}
\hline $\begin{array}{l}\text { Step } \\
\text { ID }\end{array}$ & $\begin{array}{l}\text { Step } \\
\text { Freque } \\
\text { ncy }\end{array}$ & $\begin{array}{l}\text { Implementati } \\
\text { on Details for } \\
\text { each session }\end{array}$ & Total Number of & $\begin{array}{c}\text { Total } \\
\text { estimated } \\
\text { time in } \\
\text { minutes } \\
\text { utilized for } \\
\text { manual } \\
\text { analysis for } \\
\text { all sessions }\end{array}$ & $\begin{array}{l}\text { Total } \\
\text { estimated } \\
\text { time in } \\
\text { minutes } \\
\text { utilized for } \\
\text { ICT for all } \\
\text { sessions }\end{array}$ & $\begin{array}{c}\text { Total } \\
\text { estimated } \\
\text { time saved } \\
\text { by } \\
\text { Instructor } \\
\text { in minutes } \\
\text { using ICT } \\
\text { compared } \\
\text { to manual } \\
\text { analysis for } \\
\text { all sessions }\end{array}$ \\
\hline $\begin{array}{l}\text { 1Ai- } \\
\text { Att }\end{array}$ & Daily & $\begin{array}{l}\text { Attendance } \\
\text { analysis in } \\
\text { register vs. } \\
\text { Excel }\end{array}$ & Sessions $=47$ & 73 & 18 & 55 \\
\hline $\begin{array}{l}\text { 1Ai- } \\
\text { Att }\end{array}$ & Weekly & $\begin{array}{l}\text { Attendance } \\
\text { analysis in } \\
\text { register vs. } \\
\text { Excel }\end{array}$ & Weeks $=13$ & 195 & 13 & 182 \\
\hline $\begin{array}{l}\text { lBi- } \\
\text { Cos }\end{array}$ & Per CO & $\begin{array}{l}\text { Mapping of } \\
\text { LOs to CO - } \\
\text { Manual Vs } \\
\text { Inpods }\end{array}$ & $\mathrm{COs}=6$ & 47 & 18 & 29 \\
\hline $\begin{array}{l}\text { 1Di- } \\
\text { PRTe } \\
\text { st }\end{array}$ & Once & $\begin{array}{l}\text { Evaluation and } \\
\text { analysis of Pre- } \\
\text { Requisite test - } \\
\text { Manual Vs. } \\
\text { Inpods }\end{array}$ & PRTest = 1 & 30 & 9 & 21 \\
\hline $\begin{array}{c}3 \mathrm{i}- \\
\text { FLA } \\
\mathrm{E}\end{array}$ & $\begin{array}{l}\text { Once } \\
\text { every } \\
\text { week }\end{array}$ & $\begin{array}{l}\text { Analysis of } \\
\text { FLAE - } \\
\text { Manual vs. } \\
\text { Microsoft } \\
\text { Azure \& } \\
\text { Inpods }\end{array}$ & FLAs $=13$ & 910 & 195 & 715 \\
\hline $\begin{array}{l}3 \text { ii- } \\
\text { SAD }\end{array}$ & $\begin{array}{l}\text { Once } \\
\text { every } \\
\text { week }\end{array}$ & $\begin{array}{l}\text { SAD - Manual } \\
\text { vs. Microsoft } \\
\text { Office Mix }\end{array}$ & $\mathrm{SAs}=13$ & 715 & 117 & 598 \\
\hline $\begin{array}{l}3 \mathrm{ii}- \\
\text { SAE }\end{array}$ & $\begin{array}{l}\text { Once } \\
\text { every } \\
\text { week }\end{array}$ & $\begin{array}{l}\text { SAE - Manual } \\
\text { Vs. Microsoft } \\
\text { Office Mix }\end{array}$ & $\mathrm{SAs}=13$ & 260 & 130 & 130 \\
\hline $\begin{array}{l}\text { 3iii- } \\
\text { RSFS }\end{array}$ & $\begin{array}{l}\text { Once } \\
\text { every } \\
\text { month }\end{array}$ & $\begin{array}{c}\text { RSFS - } \\
\text { Summarizing } \\
\text { Manually vs. } \\
\text { Google Forms } \\
\end{array}$ & RSFS $=3$ & 66 & 15 & 51 \\
\hline $\begin{array}{c}4 \mathrm{i}- \\
\text { ALA }\end{array}$ & $\begin{array}{c}\text { Once } \\
\text { every } \\
\text { two } \\
\text { weeks } \\
\end{array}$ & $\begin{array}{c}\text { ALA - } \\
\text { Summarizing } \\
\text { Manual Vs. } \\
\text { Inpods }\end{array}$ & $\mathrm{ALAs}=6$ & 270 & 12 & 258 \\
\hline
\end{tabular}

* The time was recorded in Hours:Minutes:Seconds format and converted to minutes as some of the results were less than an hour

6.3 Analysis of Total Estimated Time Utilized in Minutes for one Session of All Steps by Manual Analysis and ICT and Total Estimated Time Saved by Using ICT Compared to Manual Analysis. (Table 5)

Table 5 provides an analysis of 95 percent confidence limit of the time invested and time saved in minutes after applying the standard deviation. The highlight of this analysis is that the confidence limit for time saved by using ICT is very close to the time allotted.
Table 5.

Analysis of Total Estimated Time Utilized for one Session of All Steps by Manual Analysis and ICT and Total Estimated Time Saved by Using ICT Compared to Manual Analysis, their Standard Deviation and 95\% Confidence Interval

\begin{tabular}{|l|c|c|c|c|c|}
\hline \multirow{2}{*}{ Particulars } & \multirow{2}{*}{$\begin{array}{c}\text { Time } \\
\text { allotted } \\
\text { one } \\
\text { session in } \\
\text { Minutes } \\
\text { for all } \\
\text { Steps }\end{array}$} & $\begin{array}{c}\text { Time Invested } \\
\text { by Instructor } \\
\text { in minutes for } \\
\text { Manual } \\
\text { analysis for } \\
\text { one session of } \\
\text { all Steps }\end{array}$ & $\begin{array}{c}\text { Time saved } \\
\text { by } \\
\text { Instructor in } \\
\text { minutes for } \\
\text { Manual } \\
\text { analysis out } \\
\text { of total } \\
\text { allotted for } \\
\text { one session } \\
\text { of all Steps }\end{array}$ & $\begin{array}{c}\text { Time } \\
\text { Invested by } \\
\text { Instructor in } \\
\text { seconds } \\
\text { using ICT } \\
\text { for one } \\
\text { session of all } \\
\text { Steps }\end{array}$ & $\begin{array}{c}\text { Time saved } \\
\text { by } \\
\text { Instructor in } \\
\text { minutes for } \\
\text { ICT out of } \\
\text { total allotted } \\
\text { for one } \\
\text { session of all } \\
\text { Steps }\end{array}$ \\
\hline $\begin{array}{l}\text { Total time for one } \\
\text { session of all steps }\end{array}$ & 515 & 302 & 213 & 64 & 451 \\
\hline Standard Deviation & 31 & 22 & 19 & 5 & 27 \\
\hline $95 \%$ confidence limit & $484-546$ & $281-324$ & $194-231$ & $60-69$ & $423-478$ \\
\hline
\end{tabular}

* The time was recorded in Hours:Minutes:Seconds format and converted to minutes as some of the results were less than an hour

6.4Analysis of Total Estimated Time Utilized in Hours for All Sessions by Manual analysis and ICT and Total Estimated Time Saved by Using ICT Compared to Manual analysis (Table 6)

Table 6 provides an analysis of the 95 percent confidence limit in hours. It indicates that the instructor saved an estimated time of 31 to 39 hours for analysis using ICT. This amounts to approximately $78 \%$ of the total time allotted for all sessions.

Table 6.

Analysis of Total Estimated Time Utilized in Hours* for All Sessions of All Steps by Manual analysis and ICT and Total Estimated Time Saved by Using ICT

Compared to Manual analysis their Standard Deviation and $95 \%$ Confidence Interval

\begin{tabular}{|l|c|c|c|}
\hline \multicolumn{1}{|c|}{ Particulars } & $\begin{array}{c}\text { Total estimated } \\
\text { time utilized in } \\
\text { hours for manual } \\
\text { analysis for all } \\
\text { sessions }\end{array}$ & $\begin{array}{c}\text { Total estimated time } \\
\text { utilized in hours for } \\
\text { ICT for all sessions }\end{array}$ & $\begin{array}{c}\text { Total estimated time } \\
\text { saved by Instructor in } \\
\text { hours from ICT } \\
\text { compared to manual } \\
\text { analysis all sessions }\end{array}$ \\
\hline $\begin{array}{l}\text { Total time for all } \\
\text { sessions }\end{array}$ & 45 & 9 & 35 \\
\hline Standard Deviation & 5 & 1 & 4 \\
\hline $\begin{array}{l}95 \% \text { confidence } \\
\text { limit }\end{array}$ & $40-50$ & $8-10$ & $31-39$ \\
\hline
\end{tabular}

* The time was recorded in Hours:Minutes: Seconds format and converted to hours as all results were more than an hour

6.5 Analysis of Percent of Total Estimated time Saved by Instructor by using ICT Compared to Manual Analysis for all sessions of all steps (Figure 7) 
Figure 7 shows the percent time saved by the instructor by using ICT for all sessions for ten identified steps. Of the ten steps, the maximum benefit compared to all other steps was seen in FLAE (34\%), followed by SAD (28\%), ALA (12\%). Compared to all other steps, COs (1\%) \& PRTest (1\%) saved very less time.

It is also seen that $52 \%$ of total time saved was contributed by using Inpods of which $4 \%$ was along with Microsoft Office Mix for PowerPoint. Of the remaining 34\% was saved using Microsoft Office Mix for administering and verifying students' selfassessment, $12 \%$ by Excel and $2 \%$ by Google forms.

Figure 7

Analysis of Percent of Total estimated time saved by Instructor from ICT compared to manual analysis of all sessions of all steps

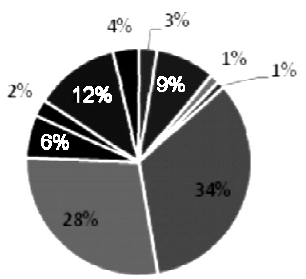

$$
\begin{aligned}
& \text { - 1Ai-Att - 1Ai-Att }=1 B i-C O S \text { - 1Di-PRTest }=3 i-F L A E \\
& \text { - 3ii-SAD - 3ii-SAE - 3iii-RSFS - 4i-ALA -5i-OA }
\end{aligned}
$$

\section{Discussions}

Atria Institute of Technology, Bangalore in collaboration with IUCEE-GENTLE program and Inpods, introduced Outcome-Based Education (OBE) for the post-graduate students of Computer Science \& Engineering program. As this was the first time the author was using OBE, it was felt that an objective assessment has to be made regarding the various components of OBE. OBE was introduced for "Managing Big Data" course and OBE was conducted as per IUCEE directions.

Administering, collecting and organizing the OBE data is an extensive process. Though it was known that use of ICT helps in saving time for other academic \& research activities, the quantity and proportion of time saved was not clear. In order to assess this advantage, the current study was designed and conducted in the initial stages of introduction of OBE.

It is observed that in addition to the ICT provided by IUCEE (Inpods), it is necessary to use other available ICTs for reasons of ease of availability and use, ICTs such as Google Forms, MS Excel 2013 and Microsoft Office Mix for PowerPoint were selected for the study. The estimates indicate that almost $78 \%$ of total time ( 35 hours saved out of 45 total time that would have been utilized for manual analysis) allotted for manual analysis of identified steps was saved by using various ICTs, which is a boon for any academician and researcher. It is also seen that more than half $(52 \%)$ of total time saved was contributed by using the main ICT, namely Inpods, which had a small contribution of $4 \%$ from Microsoft Office Mix for PowerPoint. Of the remaining, a major contribution (34\%) was from Microsoft Office Mix for administering and verifying students' selfassessment, followed by Excel (12\%) and Google forms $(2 \%)$.

In the implementation of OBE for the design of effective courses, Inpods platform provided an automation for the mapping of outcomes to course content, administering \& delivery of active learning activities, administering, delivery \& evaluation of forward-looking assessments \& self-assessments and analysis of course outcomes, student performance and Bloom's level usage in the course. For successful practicing of OBE, Microsoft Office Mix for PowerPoint assisted in creation of interactive PowerPoint presentations with quizzes and polls for empowering students to self-assess themselves and aid the instructor in administering active learning activities and monitoring students' progress and effort on self-assessment. Microsoft Office Online aided in real-time collaboration, Google Forms \& MS Excel 2013 for analytics on course feedback data. This highlights that even though ICTs like Google Forms, Microsoft Office Mix, Microsoft Office Online \& MS Excel 2013 aids the instructor in effective implementation of some of the elements of OBE model, the use of tools like Inpods provide immense support to the instructor in terms of assessing the overall quality of OBE course. Hence, the use of a major OBE ICT like Inpods along with several other available ICTs is necessary for implementation of OBE in the design of effective courses.

It is to be noted that not all activities of OBE can be performed using ICTs. If OBE is to be popularized among faculty for their regular use, it is necessary to provide assistance to them in the form of ICTs, preferably by ICTs like Inpods, to shorten the time taken to prepare some of activities such as lesson plan and schedule and defining assessment and their types which were done manually for OBE. It will also help 
immensely if these main ICTs include the features found in other available ICTs like Microsoft Office Mix, Microsoft Online, Google forms and MS Excel 2013.It was found that Microsoft \& Google offer several free online ICTs for academic purposes for improving the implementation of OBE and analysis of OBE data. Future work consists of continued analysis of other available ICTs for implementation of OBE in the design of effective courses.

To the best of the author's literature knowledge, this study is the first of its kind to collectively consider the use of existing ICTs in the application of OBE in designing effective courses and highlight through a comparison at the course level, the time invested with and without ICT usage.

\section{Conclusion \& Recommendation}

The move to Outcome Based Education(OBE) has been one of the most important trends in engineering education in recent years. However, practicing OBE manually is a labor-intensive task for instructors which can be addressed by using existing ICTs.

In this study, Inpods along with Microsoft Office Mix for PowerPoint, Microsoft Office Online, and Google Forms \& MS Excel 2013 were used for implementation of a post-graduate course namely "Managing Big Data" using the OBE model. The objectives of the study were to give prominence to the significance of ICTs in the effective implementation of OBE courses and measure the time saved when OBE is practiced using ICTs as compared to manual analysis. ICTs were used for activities ranging from course delivery, e-learning, assessment/feedback and learning outcomes analytics. The results haveshown that more than $75 \%$ of total time was saved by using various ICTs, which is a boon for any academician and researcher.

It was observed that even though ICTs like Google Forms, Microsoft Office Mix, and Microsoft Office Online \& MS Excel 2013 aided the instructor in effective implementation of some of the elements of OBE model, the use of technology platforms like Inpods provided immense support to the instructor in terms of assessing the overall quality of OBE course. Hence, the use of a major OBE ICT like Inpods along with several other available ICTs is necessary for efficient implementation of OBE in the design of effective courses. Hence, it is recommended to use one main OBE ICT along with other ICTs to significantly reduce the time taken for analysis. It will immensely benefit the academicians and researchers, if the main ICT has all necessary features required for all activities of OBE.

\section{Acknowledgement}

The author acknowledges the extensive support received from Dr. Krishna Vedula, Dr. Veena Kumar of IUCEE and Mr. Sridhar Nori, of Inpods. Without their help, the author could neither have used Inpods nor implemented OBE. The author also acknowledges the immense help received from Inpods team for smooth implementation of OBE. Thanks are due to Prof. Basavaraju M, HOD of CSE, Prof. KS Rajanandam, Principal and Dr. KV Narayanaswamy, Dean of Atria Institute of Technology, Bangalore for their approval for introducing OBE for M.Tech course. The author wishes to place on record the critical and extensive review of the article and analysis of the data by her father Dr. V H Balasangameshwara.

The paper has been completely written by the author and all sources used have been cited.

\section{References}

[1] Halkude S.A, Awasekar D.D., Nirgude M.A. and Aher S.B., "Learning Outcomes in Engineering Education: A Review of Experimentation at Walchand Institute of Technology, Solapur." Proceedings of the International Conference on Transformations in Engineering Education. Springer, (2015): 587.

[2] Bansal, Srividya, Ajay Bansal, and Odesma Dalrymple. "Outcome-based Education Model for Computer Science Education." Journal of Engineering Education Transformations 28, no. 2\&3 (2015): 113-121.

[3] Froyd, Jeffrey E., Phillip C. Wankat, and Karl A. Smith. "Five major shifts in 100 years of engineering education." Proceedings of the IEEE 100, no. Special Centennial Issue (2012): 1344-1360.

[4] Hashim, Roslan, and Mohd Din. "Implementing outcome based education using project based learning at University of Malaya." European Journal of Scientific Research 26, no. 1 (2009): 80-86.

[5] Ibrahim, Walid, Yacine Atif, Khaled Shuaib, and Demetrios Sampson. "A Web-Based Course 
Assessment Tool with Direct Mapping to Student Outcomes. "Journal of Educational Technology \& Society 18, no. 2 (2015):46-59.

[6] Fink, L. Dee. "Chapter Three: Designing Significant Learning Experiences I" in Creating significant learning experiences: An integrated approach to designing college courses. John Wiley \& Sons, 2013.

[7] Fink, L. Dee. "Integrated course design." Idea Center 42 (2005), http://ideaedu.org/wpcontent/uploads/2014/11/Idea_Paper_42.pdf

[8] Bonwell, Charles C., and James A. Eison. Active Learning: Creating Excitement in the Classroom. 1991 ASHE-ERIC Higher Education Reports. ERIC Clearinghouse on Higher Education, The George Washington University, One Dupont Circle, Suite 630, Washington, DC 20036-1183, 1991.

[9] Hattie, John, and Helen Timperley. "The power of feedback." Review of educational research 77, no. 1 (2007): 81-112.

[10] Dew, Steven K., Mathieu Lavoie, and Ashley Snelgrove. "An engineering accreditation management system." Proceedings of the Canadian Engineering Education Association (2011).

[11] LEE, B.L.P. and MAK, S., 2010. A web-based academic records tracking system for outcomebased education. In Computing in Civil and Building Engineering, Proceedings of the International Conference, W. TIZANI (Editor), 30 June-2 July, Nottingham, UK, Nottingham University Press, Paper 300, p. 599,

[12] Kerr, Barbara. "Using a Web-based assessment tool for accreditation and program improvement." In Interactive Collaborative Learning (ICL), 2011 14th International Conference on, pp. 534-538. IEEE, 2011.

[13] Essa, Eugene, Andrew Dittrich, Sergiu Dascalu, and F. C. Harris. "ACAT: a web-based software tool to facilitate course assessment for ABET Accreditation." In Information Technology: New Generations (ITNG), 2010 Seventh International Conference on, pp. 88-93. IEEE, 2010. 